Josip Lučev

University of Zagreb

Faculty of Political Science

10000 Zagreb, Croatia

josip.lucev@fpzg.hr
Dario Cvrtila

Libertas International University

10000 Zagreb, Croatia

dcvrtila@libertas.hr
JEL: E580, E650, H620, N140

Review article

https://doi.org/10.51680/ev.34.1.17

Received: February 13, 2020

Revision received: July 14, 2020

Accepted for publishing: August 31, 2020

This work is licensed under a

\title{
ECONOMIC POLICY
} INDEPENDENCE IN EU MEMBER STATES: POLITICAL ECONOMY OF CROATIAN MEMBERSHIP

\section{Abstract}

Purpose: The independence of the economic policy of national states in the European Union is a relevant and politically controversial issue as notions of lost sovereignty are often evoked by populist political options. It is therefore important to distinctly outline the actual state of affairs.

Methodology: Methodology is descriptive and comparative. The article starts by surveying traditional and recent political, institutional and economic arguments on policy convergence in areas undergoing economic integration. The article continues by contrasting the complex notion of economic sovereignty and the ongoing development of economic policy constrictions of EU (and eurozone) membership. Croatia is then compared to relevant economies in key economic policies in response to the crisis of 2008/09 in order to evaluate the maneuvering room left by the various policy constrictions.

Results: Particular attention is devoted to the comparison of exchange rate policy, fiscal policy and monetary policy employed by member states in response to the crisis of 2008/09. While economic independence in terms of crisis management is clearly reduced by virtue of EU and eurozone membership, its effects should not be felt as a change of policy direction in the case of Croatia.

Conclusion: We conclude that the policy restrictions imposed by EU membership and expected entry into the eurozone are in line with economic restraints and exhibited national policy preferences prior to EU accession.

Keywords: Economic policy constrictions, monetary policy, fiscal policy, EU, Croatia

\section{Introduction: relevance of the independence issue}

The issue of economic policy independence for EU members is relevant at least for two reasons. Firstly, it is politically contested, and it may be operationalized as threatening national sovereignty or wellbeing. Secondly, it is economically contested, as differing schools of thought have conflicting opinions on economic integration and policy convergence.
Therefore, it is important to tackle the issue with regard to the political economy of the matter, in hopes of adding to the existing scientific discourse.

Independence of economic policy of national states in the European Union is often evoked by populist political options, providing an increasingly pressing political issue. Populism has swept the developed world since the crisis of 2008/09. Its proponents claim to represent the authentic will of the people, unlike the political mainstream, and often carry a 
protectionist message - frequently viewing the market relations with other countries as inherently exploitative. In the US, a gradual shift in the Republican Party eventually culminated in the Trump presidency, vowing to "make America great again" by putting America first and draining the swamp of Washington bureaucracy. In Europe, a wave of parties emerged to challenge the prevailing political elites, often using an anti-EU platform. From UKIP and Brexit Party in the UK and Alternative für Deutschland in Germany to Movimento 5 Stelle in Italy, Syriza in Greece and Živi zid in Croatia these parties often find their countries exhausted by their foreign economic ties, and the various constrictions stemming from EU membership (e.g. austerity or migration) and must put themselves first, which they cannot do as long as they are pressured by the bureaucracy in Brussels.

The economic side of the debate is also vibrant, with the more economically liberal leaning economists generally favoring economic integrations as a path to a broader scope for market- based coordination, while prominent Keynesians like Paul Krugman and Joseph Stiglitz find fault with the deeper end of integrations - particularly the common currency at the center of the European project itself and procyclical austerity measures at the center of its fiscal integration aspect. In this context, much energy has been devoted to discussing Optimum Currency Area criteria with the goal of ascertaining whether or not the euro harmed the economic prospects of the less competitive EU members.

The objective of this text is to assess the level of economic independence in Croatia as an EU member, focusing on anti-crisis policies. The methodology is descriptive and comparative. The following two sections will offer an overview of relevant literature covering both traditional arguments on policy convergence and recent research on economic independence in the EU and EMU. Section 3 will also outline the concepts of economic independence and economic sovereignty and their growing constriction within the EU and EMU through post 2008/09 institutional reforms. Section 4 compares Croatian post-2008 national economic policies to strategies in EU member states (fiscal policy, exchange rate policy and general monetary policy). Section 5 offers an interpretation of the somewhat specific Croatian position and strengthens the overall argumentation by providing the limited data on the policy responses to the still developing COVID recession of 2020. Section 6 concludes and suggests promising avenues for future research.

\section{Arguments for and against economic policy convergence}

In its essence, the European project is an economic integration - and a harmonization of various economic policies is its important component. It started as an international strategic management of coal and steel resources, but developed into a customs union, single market and, finally, economic and monetary union. This step was symbolically vital as it introduced the salient common currency. However, it is very widely criticized as having been premature and destabilizing, crucially contributing to the macroeconomic imbalances which have made the 2009 recession and its aftermath so painful from the European perspective (e.g. Krugman, 2012; Stiglitz, 2016). It should be helpful to provide a brief overview of traditional arguments, as well as the state of recent debates on economic policy convergence in EU member states.

\subsection{Traditional arguments}

At the basic theoretical level, closer trade integration is viewed as a positive outcome by definition. Today, this position is dominant amongst economists and social scientists in general and stands at the basis of liberalism, as it is traditionally construed in the context of International Relations and International Political Economy. In fact, it has been dominant since Adam Smith's refutation of mercantilists thought in 1776, gaining further traction though David Ricardo's comparative advantage spin on Smith's argument in 1817, the HeckscherOhlin argument publication in 1933 and its further corollaries. These specific approaches have their clear differences, but at the heart of all of these is the conviction that close trade integration provides mutually beneficial specialization of all economies involved. Free trade forces all economies to specialize in what they may produce most competitively and leads to the best possible outcome in terms of goods available for consumption globally.

For markets to be fully efficient, free trade becomes a necessity, and any policy which inhibits it is not considered desirable: the overt ones, such as customs and quotas, and the covert ones, like the regulatory burden in the product markets. The deeper the integration, the broader the need for policy coordination, and it soon moves far beyond trade policy. Most notably, the creation of the common currency has brought forth issues of urgency considering the appropriate institutional framework to support the new currency. A salient position in this debate has been taken by the Optimum Cur- 
rency Area (OCA) literature (starting with Mundel, 1961, and McKinnon, 1963), which attempted to outline the institutional underpinnings of a successful currency union. This success could best be measured by the absence of asymmetric shocks such as the ones that obviously befell the eurozone in the post-2008 phase. However, at the beginning of the introduction of the euro, the consensus was shifting in favor of currency unions (for a contemporary review see Mongelli, 2002), and the political and symbolical drive towards a common currency was joined by the obvious traditional arguments in its favor. These included avoiding currency fluctuations (and therefore facilitating trade and investment) and better macroeconomic policy (Sandbu, 2015, p. 15-16).

In terms of general outlook, the liberal school of international trade has been somewhat supplanted by the more nuanced approach in the New trade theory (starting with Dixit \& Stiglitz, 1977), which is not against free trade, but does recognize that large clusters of production may have a competitive edge over smaller and developing economies due to economies of scale. In other words, free trade may also have adverse effects in certain situations and for certain economies. From New trade sprouted the New economic geography and the continued focus on the geographically divergent results of free trade. In effect, we could argue that the free market in trade, although generally positive, does not necessarily create an equally positive outcome for all parties concerned. Therefore, we could also argue that the policy-convergence underpinnings of economic integration become a supremely political issue. In other words, some economies may have far greater interests in promoting closer economic integration within the same space than others.

An additional argument comes to us in the form of literature on comparative capitalisms, best exemplified by the Varieties of Capitalism approach (Hall \& Soskice, 2001; Becker, 2009; Nölke, 2016). The basic idea is that, in terms of policies and institutions, there is more than one path to economic success and development. The original iteration of this literature (i.e. the Hall and Soskice edited volume of 2001) argued for the existence of coordinated market economies (CMEs) and liberal market economies (LMEs). The first group (exemplified by Germany and Japan, but including Nordic countries, Austria, Switzerland, Belgium and the Netherlands) developed specific skill sets, slowmoving bank-centric financial systems, strong and active trade unions and other strategically oriented institutional solutions. The second group (exem- plified by the USA, but including Canada, Ireland, the UK, Australia and New Zealand) developed non-specific skill sets, fast-moving stock-marketcentric financial systems, weak trade unions and other free-market oriented institutional solutions. In terms of growth, both worked, but in very different complementary ways. Growth was logically tied to the consistent selection of compatible policies, which formed at least two distinct sets. The subsequent generations of research focused on overcoming this binary structure and including a much wider array of countries, but also on introducing more variables. Of particular interest to us is the strand of literature that focused on macroeconomic management policies (e.g. Carlin \& Soskice, 2009; Hall \& Gingerich, 2014). These authors developed the idea that conservative fiscal policy is essentially favored by CME countries as it is compatible with their policy choices. Likewise, discretionary fiscal policy is favored by LME countries. This creates a possible problem, as it could mean that the macroeconomic monitoring structure that has developed in the past ten years in the EU is essentially the promotion of policies that are favored by Germany, but perhaps work to the detriment of many other member states, as they remain incompatible with the rest of their institutions and policies.

\subsection{Recent debates}

In terms of convergence, EMU has produced high degrees of GDP and consumption synchronization among the twelve core member states (Imbs \& Pauwels, 2019). However, the asymmetric shocks since 2008 have drawn criticisms of the eurozone along the lines of OCA (see Krugman, 2013; Eichengreen, 2014). Some of the crucial reforms within the eurozone (see the following section) have followed the OCA criteria in that a significant issue was found to be the absence of a fiscal union. This has enacted a policy convergence in the macroeconomic management field, through which a similar approach to fiscal policy is enforced, and whereby conservative and effectively pro-cyclical fiscal policy is intended to preserve the euro. This fiscal policy conservatism is a particular thorn in the Keynesian side of the debate, as the equalization of fiscal policies in crises suggests a failure of aggregate demand management in an economically integrated area. As the argument goes, Germany could have offset the necessary austerity programs on the periphery of the eurozone by conducting a massive fiscal stimulus, which would have provided an export market for the peripheral economies. However, if the general prescription is for all countries to enact austerity at 
once, then the result can only be a protracted recession as the economically integrated area provides a very relevant network of export markets - and the universal austerity suggests that the bulk of exports contracts from the perspective of any given country (Krugman, 2012; Gaysset et al., 2019). This antiinterventionist streak invites criticism towards an overly free-market or "neoliberal" orientation of the EU (e.g. Lütz \& Kranke, 2014). However, it is worth noting that the policies favored in the European Semester (see below) are not always free-market oriented. Haas et al. (2020) code the Country Specific Recommendations in order to ascertain if they are dominantly in favor or against government intervention and conclude that the frequent calls for fiscal restraint and labor market flexibilization are tempered by social protection concerns. This is a significant issue as institutionally oriented research suggests that this deliberate influence may be in conflict with national varieties of capitalism and their growth models which may be discerned even in small and open economies (Johnston \& Regan, 2018; Bohle, 2018).

Specific national contexts clearly have both an economic and a political component. In terms of economic context, EMU itself clearly provides a new playing field. Obstfeld (2013) and Canale et al. (2018) approach the issue of economic policy constrictions in the eurozone through the famous open economy policy trilemma of the early 1960s Mundell-Fleming model in which only two of three desirable objectives (fixed exchange rates, independent monetary policy and free capital mobility) can plausibly be maintained. With the elimination of national monetary policies through the euro, and the institutional reforms since the 2009 recession, the issue is transformed. Free capital mobility is now joined by fiscal policy flexibility and financial stability as the new trilemma providing a modern set of policy constrictions for the eurozone members. It is also clear that in the wake of Brexit, political issues increase in visibility, as it is not only economic arguments, but their legitimacy and support that will drive the outcomes of the process of European integration. However, Târlea et al. (2019) offer a reminder that these issues are always entangled. They analyze a governmental preferences dataset and conclude that economic factors are far better predictors of support for high degrees of European integration than political factors (e.g. public opinion or presence of Eurosceptic parties). Particularly, the exposure of the financial sector is found to be the most important element in inducing governments in the direction of integration.
Finally, from the point of view of Croatia, the entry into the eurozone is favored as the monetary and exchange rate policy is already geared towards the euro. This suggests that losing exchange-rate flexibility is not a significant issue as its maneuvering space is extremely limited already. On the other hand, the positive sides for a small, open economy include political influence, trade and investment, greater macroeconomic and financial stability, access to the ECB's refinancing facilities removing the risks of high shares of foreign-currency in the financial system (Dabrowski, 2019, p. 40)

\section{Constrictions to national policy in the EU}

Sovereignty from an economic viewpoint may be defined as "supreme legal authority within the geographical boundaries of the nation, giving national authorities autonomy over the regulation of economic activity inside the country through legislation, administration, and judicial enforcement" (Kletzer, 2018, p. 12721). The autonomy to formulate economic policy, particularly in response to crises could also be added to this definition. In this respect, the notion of sovereignty or independence could be seen as antithetical to EU membership. EU has clearly moved far beyond mere market integration, and its integration process includes the pooling of core state powers such as money and fiscal affairs (Genschel \& Jachtenfuchs, 2018). The most intensive integration revolves around the eurozone issue. Two decades ago, the project of European integration was marked by the discrepancy of the euro as a currency without a state, whereby the EU itself became a polity in the making (Padoa-Scioppa, 2004, p. 35). However, in the reform-oriented experimentation in transcending the missing state, national sovereignties of the EU member states are logically impinged upon. The very development of EU and eurozone has been marked by the maneuvering around sovereignty at each turn, and its continuation may involve a choice between breaking the national sovereignty barrier altogether and slowly disentangling by returning fiscal sovereignty to member-states (Mody, 2018).

However, it should be clear that sovereignty is not relinquished by entering the European Union, as member states partake in the decision making process and may leave the Union if dissatisfied. It should also be clear that the nature of economic governance in the EU is complex and is not clearly described either by intergovernmentalism (which would retain sovereignty) or supranationalism (which would not) (Schmidt, 2016). The very con- 
cepts of sovereignty and independence must therefore be understood as subtle and fluid.

It is perhaps more useful to focus on the specific ways in which the maneuvering space of economic policies is constricted. The formation of the eurozone as the closest type of economic integration within the EU was followed uncomfortably closely by the disastrous consequences of the 2008 financial crisis, the 2009 recession, and the Sovereign Debt Crisis in 2010. These manifested differently across member states providing the EU with an asymmetrical shock which underlined two further asymmetries. Namely, from its beginnings EMU revolved around an asymmetry of integration with more integration in the "monetary union" and less in the "economic union". The third asymmetry was made obvious with the handling of the debt crisis - one between the core and the periphery of the eurozone (Howarth \& Verdun, 2020). The political aspects of the European project were shaken to the core (as mentioned in Section 1, with current political consequences as well), and the euro was taken under scrutiny, allowing for a rethinking of available mechanisms in order to supply a better supporting architecture for this more advanced stage of economic integration. The two general directions in which these evolved were the formulation of a stability mechanism (to support the countries hardest hit) and a fiscal integration (to prevent policy variety in terms of fiscal responsibility). Table 1 summarizes these developments.

Table 1 New institutional mechanisms favoring macroeconomic management convergence

\begin{tabular}{|c|c|}
\hline $\begin{array}{l}\text { DATE } \\
\text { OF REFORM }\end{array}$ & TYPE OF REFORM AND SHORT DESCRIPTION \\
\hline May 2010 & $\begin{array}{l}\text { European Financial Stabilization Mechanism } \\
\text { Ad hoc instrument created for the financial support of Ireland and Portugal } \\
\text { Maximum capacity of providing } 60 \text { billion euro } \\
\text { Backed by the budget of the EU }\end{array}$ \\
\hline May 2010 & $\begin{array}{l}\text { European Financial Stability Facility } \\
\text { Ad hoc instrument used for providing the needed financial assistance to Ireland, Portugal and Greece. } \\
\text { Capacity to issue } 440 \text { billion euro } \\
\text { Guaranteed by member states }\end{array}$ \\
\hline January 2011 & $\begin{array}{l}\text { European Semester } \\
\text { Timetable annual for the surveillance of national economic policies before they are adopted by mem- } \\
\text { ber states }\end{array}$ \\
\hline $\begin{array}{l}\text { December } \\
2011\end{array}$ & $\begin{array}{l}\text { Six-pack } \\
\text { Reinforcement of Stability and Growth Pact, providing greater sanctions for the failure to meet the } \\
\text { convergence criteria of public debt kept below } 60 \% \text { of GDP and budget deficits kept below } 3 \% \\
\text { Includes the Macroeconomic Imbalances Procedure }\end{array}$ \\
\hline October 2012 & $\begin{array}{l}\text { European Stability Mechanism } \\
\text { Permanent stability mechanism (effectively replacing EFSM and EFSF) used to provide financial as- } \\
\text { sistance to Cyprus, Spain and Greece } \\
\text { Maximum lending capacity at } 500 \text { billion euro, with an additional } 200 \text { billion invested in the financial } \\
\text { markets }\end{array}$ \\
\hline $\begin{array}{l}\text { November } \\
2012\end{array}$ & $\begin{array}{l}\text { Fiscal compact } \\
\text { Intergovernmental treaty binding for } 19 \text { eurozone members, and Romania, Bulgaria and Denmark } \\
\text { as opt-ins } \\
\text { The fiscal compact further strengthening budgetary discipline }\end{array}$ \\
\hline May 2013 & $\begin{array}{l}\text { Two-pack } \\
\text { Strengthening of surveillance and coordination but introducing no additional policy requirements }\end{array}$ \\
\hline $\begin{array}{l}\text { November } \\
2014\end{array}$ & $\begin{array}{l}\text { Single Supervisory Mechanism } \\
\text { New capacity for financial regulation of eurozone members for the ECB }\end{array}$ \\
\hline
\end{tabular}

Source: Hodson (2015, p. 179); ESM (2019); Maletić et al. (2019)

The changes summarized in Table 1 enabled a more comprehensive process of policy harmonization with the European Semester combining the Stability and
Growth Pact with the Europe 2020 strategy (smart growth, sustainability, inclusiveness) with the new Macroeconomic Imbalances Procedure (which ex- 
panded surveillance to private debt, financial sector and unemployment). These changes also strengthened the existing framework - i.e. the Stability and Growth Pact, which was in place since the late 1990s as an attempt to enforce the Maastricht criteria on debt $(60 \%$ GDP) and deficit (3\% GDP). The Pact now has effective preventive and corrective arms, and Croatia has found itself subjected to the latter, i.e. the Excessive Deficit Procedure (EDP) for the violation of both the debt and deficit rules in the January 2014-July 2017 period. EDP provided goals in deficit management for the 20142016 period, and Croatia managed to sufficiently control the deficit in 2015 and 2016 in order to successfully exit the EDP (see Maletić et al., 2019).

The European Semester brought complex and subtle changes to policy coordination with the effect of achieving coordination of economic policies without further transferring of sovereignty to the EU level (Verdun \& Zeitlin, 2018). However, these constrictions on economic independence depend on the legitimacy for political sustainability. Crum and Merlo (2020) note that the monetary and economic aspects of EMU have depended on different types of legitimation, with the monetary aspect relying on output legitimacy (legitimized by the resulting visible improvements) and the economic aspect relying on input legitimacy (legitimized by the transparent and democratic political input). This is significant as European economic governance increasingly acts as a constraint on both governments' decisions on fiscal policy and the ability of parliaments to contest them, which suggests a significant loss of input legitimacy (Crum \& Merlo, 2020, pp. 406-407).

Parliaments are generally expected to oversee fiscal policy by scrutinizing and approving a budgetary proposal forwarded by the government. While the post-crisis reforms did nothing to formally diminish such oversight, supranational surveillance increased its "scope, depth and bite" (Crum, 2018, p. 273), and realistically pushed governments into a "defensive and reactive mode" (ibid, p. 274). National parliaments themselves would sometimes respond by seeking a more proactive role, and it is worth noting that the diminishing power of parliaments with respect to budgets represents a historical trend that far precedes the post-crisis reforms of European economic governance (Jančić, 2016).

In a more general sense, the reforms outlined in Table 1 strengthened the economic policy harmonization in the areas that were deemed necessary to complement the high, but apparently unfinished stage of economic integration of a common currency. In this sense, the level of economic integration, if it is con- sistent rather than self-defeating, logically constricts economic policy. A free trade area or a customs union would necessarily restrict tariff policy, and still deeper integrations like the European Single Market logically extend this to factor movements (i.e. the four freedoms of movement: capital, labor, goods and services). Consistence requires harmonization starting in market regulation, and the further step toward a currency union removed the possibility of an exchange rate policy, requiring, logically, fiscal integration and financial regulation harmonization. It took a severe post-2008 asymmetric shock to propel these changes, but the vulnerability itself was a result of a faulty structure and cannot simply be ascribed to the exogenous element of the crisis. The current framework, however, completes the logical sterilization of independent anti-cyclical economic policy. Alongside the old removal of international trade policy, and the implicit removal of exchange rate and monetary policy for eurozone members, we must now also accept the inability of independent fiscal response. The next section will take a look at how this may affect Croatia (whether the EU membership and the expected future eurozone membership change anything) in the context of various other strategies for crisis management in the EU since 2008.

\section{The past crisis responses}

The previous two sections have touched upon the complexities of economic independence in the context of European integration. As national level economic policies occur in specific institutional contexts, their consistent application may be indicative of national institutional preferences which further tie into growth models. A careful approach may help us discern whether or not future constrictions upon these can be construed to limit economic independence or merely provide stronger policy preferences without a change in their direction. This section surveys the responses to the past crisis (2008-2019) in all current EU members and the UK. It takes stock of three aspects of anti-cyclical policies: monetary, fiscal and exchange rate policy - in order to compare those strategies to the increasingly narrow maneuvering space given to individual states by the developing architecture of macroeconomic constraints described above. We focus on Croatia in order to be able to conclude on evolving position of economic policy availability.

\subsection{Depreciation episodes}

Figure 1 shows monthly changes to exchange rates against the euro in the 2008-2011 period. The data suggest significant depreciation episodes in late 2008 and early 2009 for several economies. 
Figure 1 Nominal exchange rates in current non-euro EU members in 2008-2011 (monthly \% change against EUR)

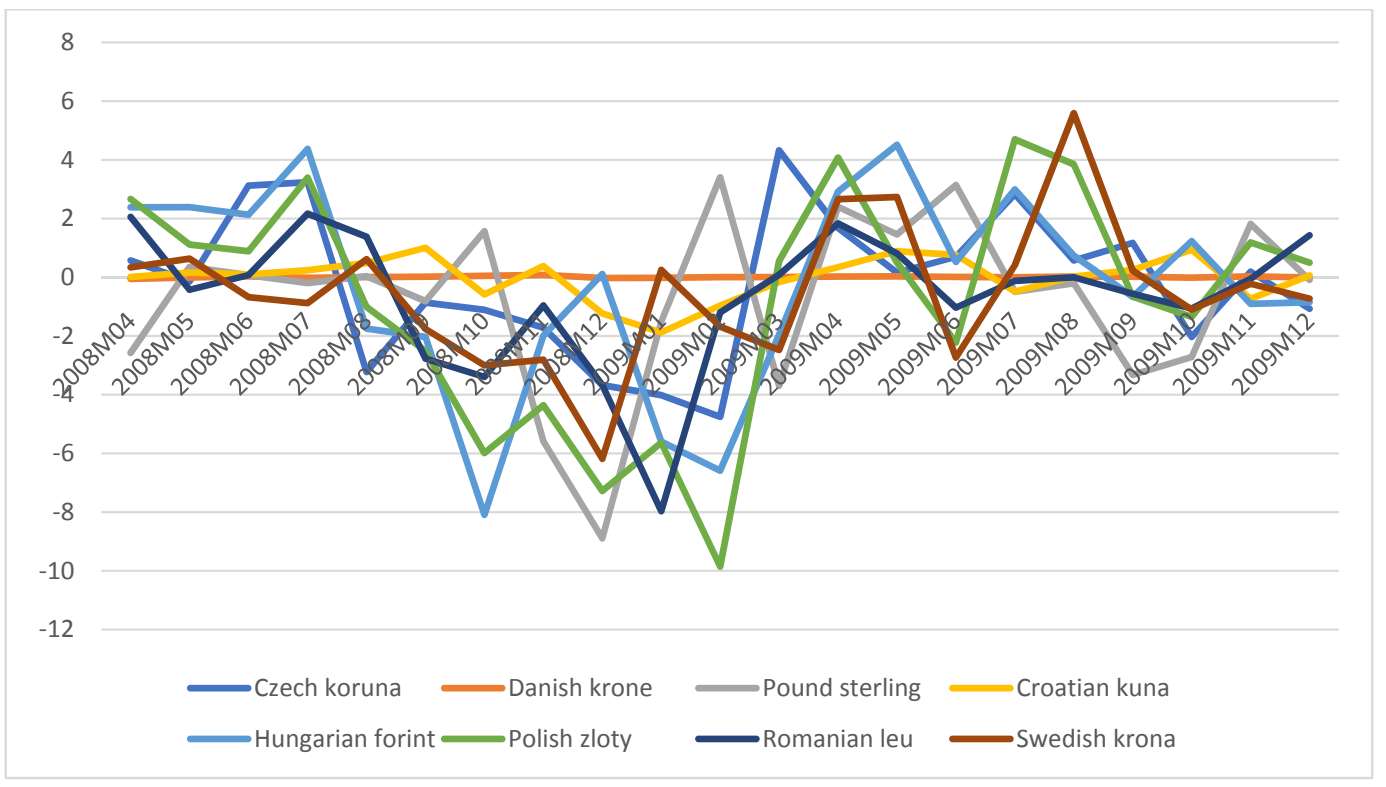

Source: Own calculation based on Eurostat (2019) ${ }^{1}$ - Euro/national currency exchange rates

Polish złoty would reach the record monthly nominal depreciation of $9.9 \%$ against the euro in February 2009, and the average exchange rate in 2009 was a substantial $23.4 \%$ weaker against the euro compared to the average rate for 2008. Pound sterling would depreciate at the record monthly rate of $8.9 \%$ in December 2008 (the yearly nominal average for 2009 was $11.3 \%$ weaker compared to the average for 2008 , or $30.9 \%$ weaker compared to the average for 2007 ). The Hungarian forint would depreciate at the record nominal rate of $8.1 \%$ in October 2008 (the yearly nominal average for 2009 was $11.5 \%$ weaker compared to the average for 2008). The Romanian leu would depreciate at the record nominal monthly rate of $8 \%$ in January 2009 (the yearly nominal average for 2009 was $15.2 \%$ weaker compared to the average for 2008 , or $26.9 \%$ weaker compared to the average for 2007). Finally, the Swedish krona would depreciate at the record nominal monthly rate of $6.2 \%$ in December 2008 (the yearly nominal average for 2009 was $10.4 \%$ weaker compared to the average for 2008 , or $14.8 \%$ weaker compared to the average for 2007).

In contrast with these, Bulgarian lev did not fluctuate at all, maintained as it is by a currency board (for this reason it is not shown in the graph). Dan-

1 Eurostat (2019). https://ec.europa.eu/eurostat/data/database ish krone (as well as the Lithuanian litas, Latvian lat and Estonian krone - not shown in the figure - which existed during 2009 but were eventually introduced to the eurozone) did not fluctuate substantially. The Croatian kuna falls in between these two poles - with the record monthly depreciation rate of $1.9 \%$ in February 2009, suggesting a substantial degree of stability (and the yearly average exchange rate in 2009 only $1.7 \%$ weaker compared to the average rate for 2008). This is a result of the dedication to the stability of the HRK/EUR exchange rate as a fundamental aspect of the Croatian economy (see below). It follows that the economy most comparable to Croatia in terms of dedication to the euro exchange rate is Bulgaria, another small, post-socialist economy with high euroization of the economy. In terms of the loss of exchange rate flexibility through eurozone membership, we should add five other small, post-socialist economies of Slovenia, Slovakia, Estonia, Lithuania and Latvia.

\subsection{Fiscal response}

Figure 2 shows the changes in net lending/borrowing positions as ratios to GDP for the several years following the 2008 financial crisis (2008-2011) for all current EU member economies and the UK. 
Figure 2 Net lending/borrowing \% GDP 2008-2011

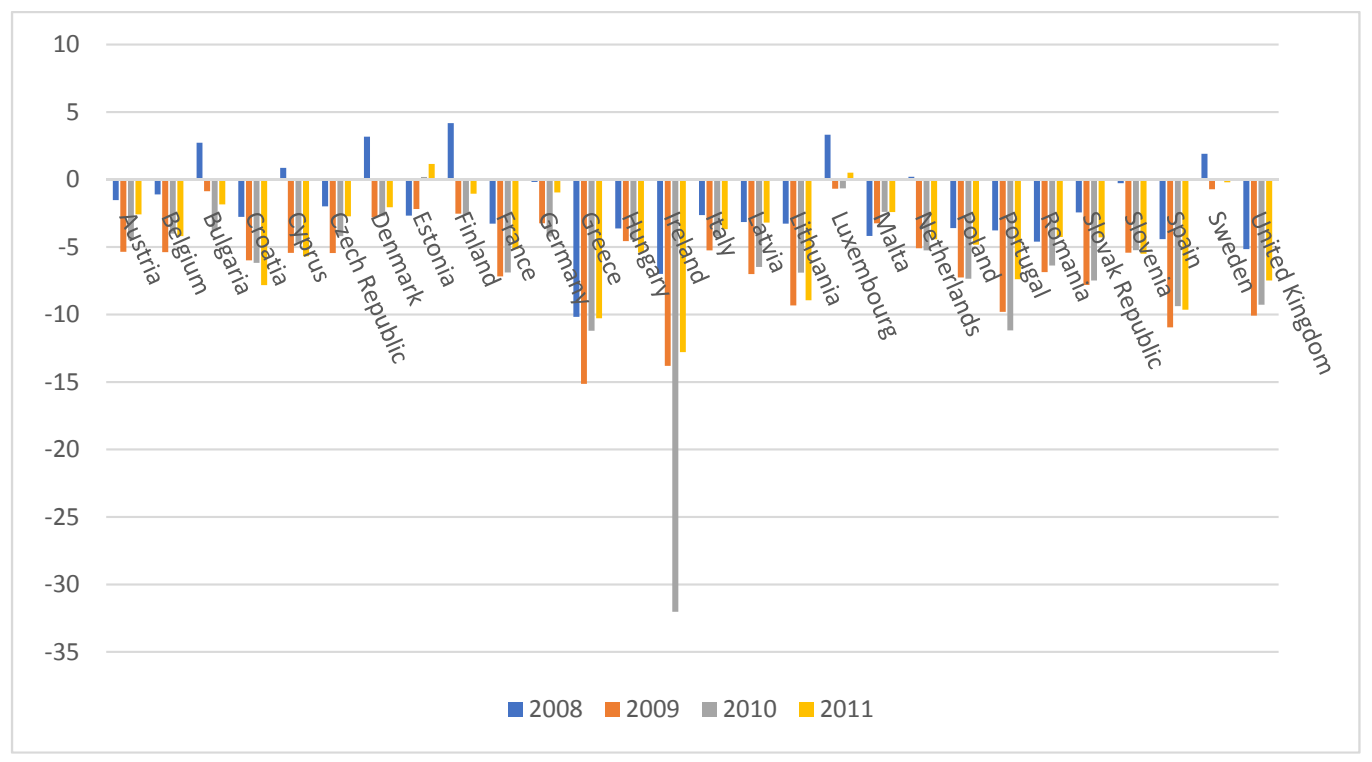

Source: IMF (2019)

The two extreme groups of countries in Figure 2 are countries with notably sound finances and those with extremely poor ones. The first group is dominated by Nordic countries (Denmark, Finland, Sweden), with the addition of Luxemburg, while the second is presided by Ireland and Greece, followed by Portugal and Spain. These four worst performers were all captured by the stabilization programs in the 20102012 period (some of these astounding deficits were clearly a result of the bail-out programs themselves, assigning funds via the national budget).

Disregarding the countries whose budgets were under the control of the conditioned stabilization, the largest fiscal activity could be seen in the UK, Lithuania, Slovakia, Poland and Croatia. Such data should be handled carefully for several reasons: firstly, the denominator effect in any data expressed as a percentage of GDP suggests it is highly sensi- tive to changes in GDP - and if GDP suffers a sharp decline, public deficits and public debt as a percentage of GDP would rise even if the nominal levels were declining as long as they were declining at a slower rate than the decline in GDP (De Grauwe and $\mathrm{Yi}, 2013)$. This suggests that periods in which countries suffer strong but variable GDP contractions are the worst periods to compare their indicators as a ratio of GDP. Secondly, a rising deficit may be a result of a falling public revenue level, an increasing public expenditure level, a deterioration in loaning conditions, or any combination of these factors. It is therefore difficult to discern specific anti-cyclical strategies merely from these data. To see how much of the change in net borrowing as a percentage of GDP was a result of fiscal stimulus, we have to compare the levels of revenue and expenditure. Figure 3 does so for Croatia. 


\section{Figure 3 Government revenue and expenditure in Croatia (millions HRK)}

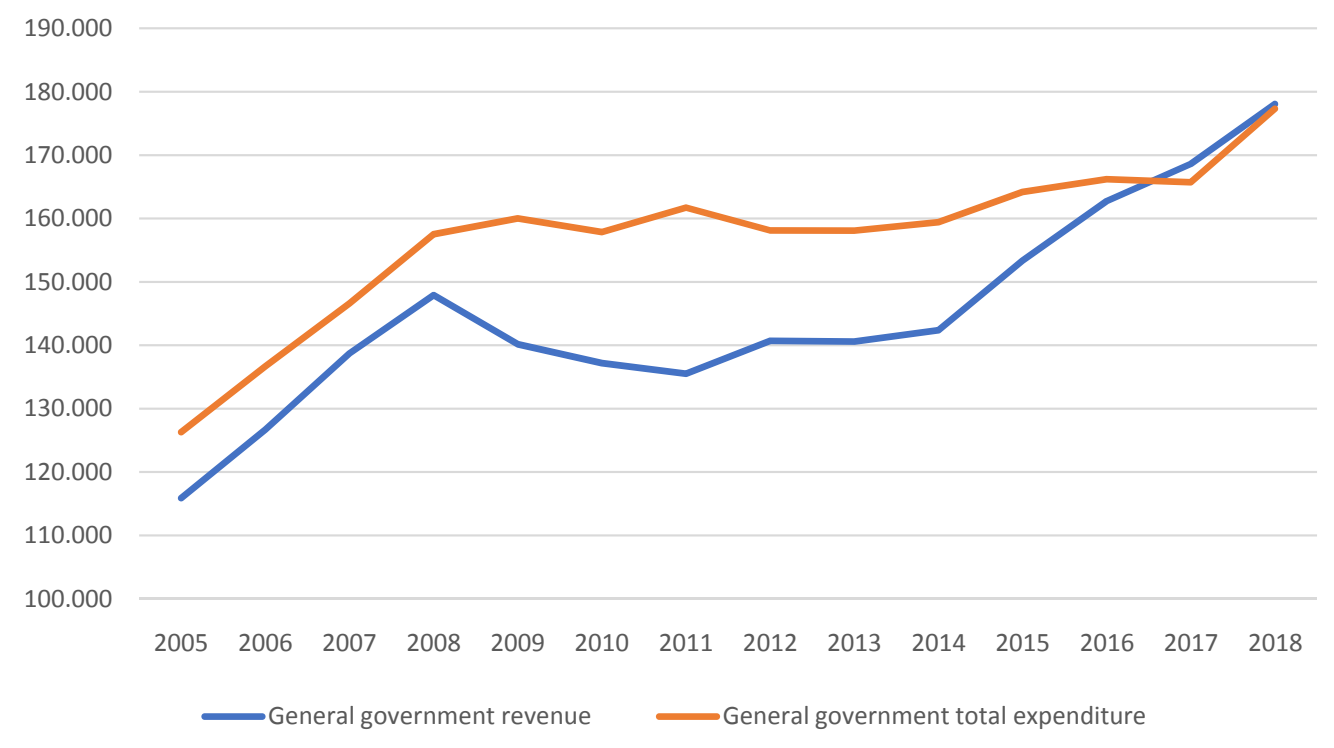

Source: IMF (2019)

The data are shown in nominal HRK. On the revenue side, there was a substantial decline in the 2008-2011 period - from 147.9 billion HRK to 135.5 billion HRK or $-8.4 \%$ (and if we correct for inflation using the index values in IMF's WEO database we reach an even steeper decline of -13.4\%). The nominal revenue levels afterwards increased, recovering to their 2008 level by 2014 (or 2016 if we correct for inflation). In comparison, the expenditure side moved very little. There was a nominal increase in the 2008-2011 period ( 4.2 billion HRK or $+2.7 \%$ ), however, if we correct for inflation, the result is a nearly $3 \%$ decrease in real expenditure (and by 2013 this would turn to a $10.25 \%$ decrease since 2008). The nominal level of
2008 expenditure was regained by 2015 , and correcting for inflation, its level was almost reached only in 2018 (99.86\%). The data on expenditure and revenue suggest that Croatian fiscal policy was certainly not involved in a fiscal stimulus and that its debt problems stemmed from the failings of the revenue side (expected during a downturn). In other words, fiscal policy exacerbated and fed the prolonged negative growth of the 2009-2014 period.

In order to provide a meaningful comparison of these two trends, we choose Slovenia, an economy with numerous structural similarities (Babić \& Lučev, 2019). 
Figure 4 Government revenue and expenditure in Slovenia (millions EUR)

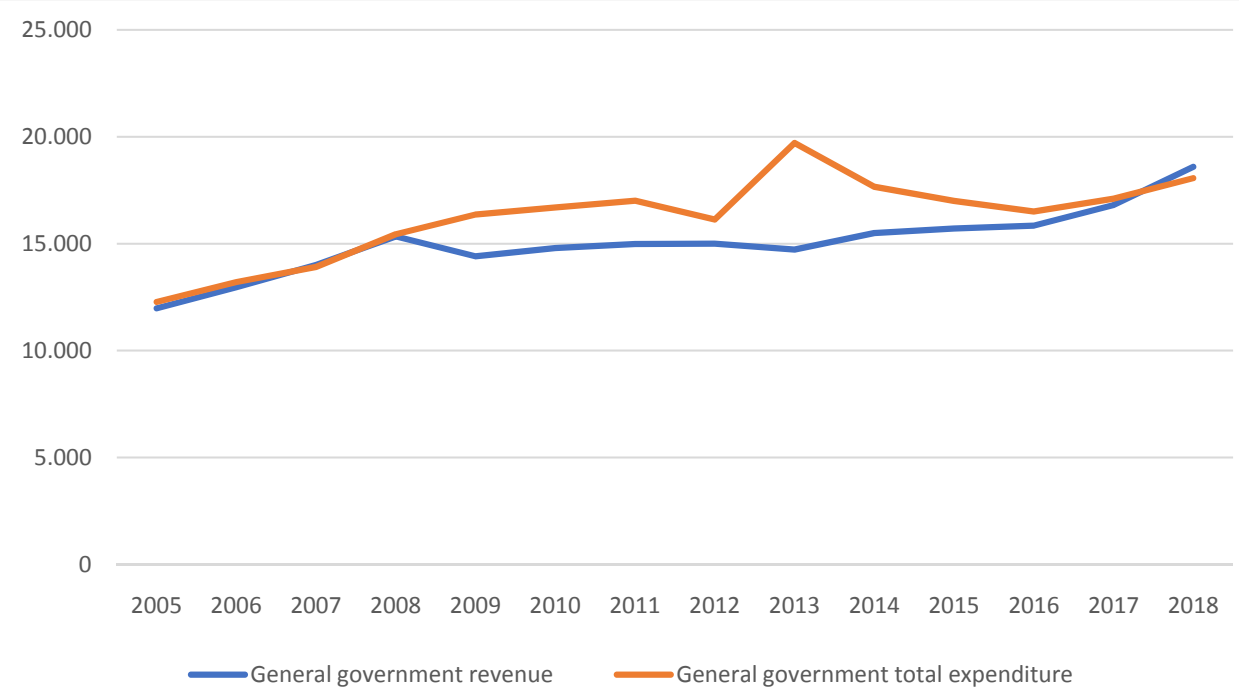

Source: $\operatorname{IMF}(2019)$

The revenue trend manifested similarly in Slovenia. The nominal revenue fell in the 2008-2010 period $(-3.5 \%)$ and again in $2013(-4 \%$ compared to 2008 level). If we recalculate taking inflation into account, we can see that in 2008 prices, revenue was 6\% lower by 2010 and 12\% lower by 2013 . However, expenditure followed a somewhat different pattern. Nominal expenditure continued growing after the recession started and fell only in 2012 (by 5.2\%) after which there was a notable increase in 2013 (by 22.2\%). Recalculating for inflation, in real terms expenditure fell by $7.6 \%$ in 2012 and grew by $20.1 \%$ in 2013 . In other words, a fall in revenue was accompanied by a more active anticyclical fiscal policy.

\subsection{Monetary response}

In the prevalent macroeconomic thought and practice before the crisis, macroeconomic policy focused on monetary policy. In turn, the prevalent crisis responses of monetary policy focused on key interest rates (Blanchard et al., 2010). Table 2 shows the trends in the traditionally minded monetary policy i.e. changes in key interest rates. It covers the period since the first responses to the 2008 financial crisis until December 2019 (prior to the development of COVID crisis, the response to which is essentially still being formulated) for ECB and all EU members (excluding the UK) currently not in the eurozone (Sweden, Denmark, Poland, Czechia, Hungary, Bulgaria, Romania and Croatia). The key interest rates are reported under the types and titles identified by the websites of the central banks themselves.

Table 2 Central banks and their key interest rates

\begin{tabular}{|l|l|}
\hline $\begin{array}{l}\text { Central } \\
\text { bank }\end{array}$ & Key interest rates trends \\
\hline ECB & $\begin{array}{l}\text { November } 2008 \text { - start of decline of deposit rate, initially from 3.25\% to 2.75\%, eventually to 0.25 - } \\
\text { initial and brief rebound in April 2011, hitting 0\% by July } 2012 \text { and negative rates since June 2014 and } \\
\text { standing at -0.5 since September 2019 (still at this level as of December 2019). } \\
\text { October 2008 - start of decline of Marginal lending facility, initially from 5.25\% to 4.75\%, initial and } \\
\text { brief rebound also in April 2011, eventually dropping to 0.25 in September 2019 (still at this level as of } \\
\text { December 2019). }\end{array}$ \\
\hline
\end{tabular}




\begin{tabular}{|c|c|}
\hline $\begin{array}{l}\text { Central } \\
\text { bank }\end{array}$ & Key interest rates trends \\
\hline \multirow{3}{*}{ Poland } & $\begin{array}{l}\text { November } 2008 \text { - start of decline of the deposit rate, initially from } 4.5 \% \text { to } 4.25 \% \text {, eventually reaching } \\
\text { its first minimum of } 2 \% \text { in June } 2009 \text {. Recovering since January } 2011 \text { eventually reaching } 3.25 \% \text { in Oc- } \\
\text { tober 2012. Dropping once more since November 2012, eventually to } 0.5 \% \text { in March } 2015 \text { (still at this } \\
\text { level as of December 2019). }\end{array}$ \\
\hline & $\begin{array}{l}\text { November } 2008 \text { - start of decline of the rediscount rate, initially from } 6.25 \% \text { to } 6 \% \text {, eventually reach- } \\
\text { ing its first minimum of } 3.75 \% \text { in June } 2009 \text {. Recovering since January } 2011 \text { eventually reaching } 5 \% \text { in } \\
\text { October } 2012 \text {. Dropping once more since November 2012, eventually to } 1.75 \% \text { in March } 2015 \text { (still at } \\
\text { this level as of December 2019). }\end{array}$ \\
\hline & $\begin{array}{l}\text { November } 2008 \text { - start of decline of the Lombard rate, initially from } 7.5 \% \text { to } 7.25 \% \text {, reaching its first } \\
\text { minimum of } 5 \% \text { in June } 2009 \text {. Recovering since January 2010, it eventually reached } 6.25 \% \text { by October } \\
\text { 2012, dropping once more since November } 2012 \text { to reach 2.5\% by March } 2015 \text { (still at this level as of } \\
\text { December 2019). }\end{array}$ \\
\hline \multirow{3}{*}{ Czechia } & $\begin{array}{l}\text { August } 2008 \text { - start of decline of the discount rate, initially from } 2.75 \% \text { to } 2.50 \% \text {, eventually dropping } \\
\text { to } 0.05 \% \text { in November } 2012 \text { and then slowly recovering from August 2018, at } 1.00 \% \text { since May } 2019 \text {. }\end{array}$ \\
\hline & $\begin{array}{l}\text { August } 2008 \text { - start of decline of the Lombard rate, initially from } 4.75 \% \text { to } 4.50 \% \text {, steadily reaching } \\
0.25 \% \text { by November 2012, recovering since August } 2017 \text { and standing at 3\% since May } 2019 \text {. }\end{array}$ \\
\hline & $\begin{array}{l}\text { August } 2008 \text { - start of decline of the repo rate, initially from } 3.75 \% \text { to } 3.50 \% \text {, eventually reaching } 0.05 \% \\
\text { in November } 2012 \text { and recovering since August 2017, standing at } 2 \% \text { since May } 2019 \text {. }\end{array}$ \\
\hline Sweden & $\begin{array}{l}\text { October } \mathbf{2 0 0 8} \text { - start of decline of the repo rate, initially from } 4.75 \% \text { to } 4.25 \% \text {, reaching its first mini- } \\
\text { mum in April } \mathbf{2 0 1 0} \text { at } 0.25 \% \text { and recovering from July } \mathbf{2 0 1 0} \text { to eventually reach } 2 \% \text { in July } \mathbf{2 0 1 1} \text {. Drop- } \\
\text { ping again since December } \mathbf{2 0 1 1} \text {, initially to } 1.75 \% \text { and eventually reaching negative territory in Febru- } \\
\text { ary } 2015 \text { and a new minimum of - } 0.50 \% \text { in February } \mathbf{2 0 1 6} \text {. Recovering once more since January } 2019 \\
\text { and slated to reach } 0 \% \text { in January } 2020 \text {. }\end{array}$ \\
\hline Hungary & $\begin{array}{l}\text { November } 2008 \text { - start of decline of the base rate, initially from } 11.5 \% \text { to } 11 \% \text { and eventually to its first } \\
\text { minimum of } 5.25 \% \text { in April 2010. Recovering from November } 2010 \text { to } 7 \% \text { in December 2011, and } \\
\text { dropping to } 0.9 \% \text { in May } 2016 \text { (still at this level as of December 2019). }\end{array}$ \\
\hline \multirow[t]{2}{*}{ Romania } & $\begin{array}{l}\text { February } 2009 \text { - start of decline of the deposit rate, initially from } 6.25 \% \text { to } 6 \% \text { and eventually to its first } \\
\text { minimum of } 1.25 \% \text { March 2012, recovering briefly to } 2.25 \% \text { in May 2013, and resuming its decline since } \\
\text { July 2013, reaching } 0.25 \% \text { in August 2014. Recovering since October } 2017 \text { and standing at } 1.5 \% \text { as of } \\
\text { December } 2019 \text {. }\end{array}$ \\
\hline & $\begin{array}{l}\text { February } 2009 \text { - start of decline of the Credit facility rate, initially from } 14 \% \text { to } 13.5 \% \text { and eventually to } \\
2.75 \% \text { in November } 2017 \text {. Recovering since January } 2018 \text { this rate stands at 3.5\% as of December } 2019 \text {. }\end{array}$ \\
\hline \multirow[b]{2}{*}{ Croatia } & $\begin{array}{l}\text { June } 2011 \text { - the first of two decisions to reduce the discount rate - initially 9\% to 7\% and then to } 3 \% \text { in } \\
\text { October } 2015 \text { (still at this level as of December 2019). }\end{array}$ \\
\hline & $\begin{array}{l}\text { November } 2011 \text { - the first of three decisions to reduce the Lombard rate, initially from } 9 \% \text { to } 6.25 \% \text {, and } \\
\text { then to } 5 \% \text { in December } 2013 \text { and } 2.5 \% \text { in October } 2015 \text { (this category was switched to the overnight } \\
\text { credit rate in September } 2017 \text { at the same level as of December 2019). }\end{array}$ \\
\hline Bulgaria & $\begin{array}{l}\text { January } 2009 \text { - start of decline in the base rate, initially from 5.77\% to 5.17\%, and, apart from very brief } \\
\text { and slight upticks consistently dropping (reaching below 0.1\% in August 2018), at 0\% as of December } 2019 .\end{array}$ \\
\hline \multirow{2}{*}{ Denmark } & $\begin{array}{l}\text { November } 2008 \text { - start of decline of the discount rate, initially from } 4.5 \% \text { to } 4 \% \text {, eventually reaching } \\
\text { its first minimum of } 0.75 \% \text { in January 2010, slightly recovering since April 2011, eventually to } 1.25 \% \\
\text { in July } 2011 \text { and dropping since November 2011, reaching } 0 \% \text { in July } 2011 \text { (still at this level as of De- } \\
\text { cember 2019). }\end{array}$ \\
\hline & $\begin{array}{l}\text { November } 2008 \text { - start of decline of the lending rate, initially from } 5.5 \% \text { to } 5 \% \text {, eventually reaching its } \\
\text { first minimum of } 1.05 \% \text { in January } \mathbf{2 0 1 0} \text {, slightly recovering since April } \mathbf{2 0 1 1} \text {, eventually to } 1.55 \% \text { in } \\
\text { July } 2011 \text { and dropping since November } 2011 \text { (disregarding a slight uptick from } 0.2 \% \text { to } 0.3 \% \text { in the } \\
\text { January-May } 2013 \text { period), reaching } 0.05 \% \text { in January } 2015 \text { (still at this level as of December } 2019 \text { ). }\end{array}$ \\
\hline
\end{tabular}

Sources: ECB (2019); CNB (2019); Riksbank (2019); NBP (2019); Danmarks Nationalbank (2019); HNB (2019); BNR (2019); $M N B$ (2019); $B N B$ (2019) 
Table 2 shows that almost all covered countries first responded in the August-November 2008 period. Bulgaria and Romania were slightly late and had their first reductions in January and February 2009. However, the real outlier is Croatia, which only reduced its key rates in 2011.

We have chosen the interest rates as the prevalent and easily comparable response, but monetary policy was naturally not limited to these changes (although the various expansionary measures adopted across various economies cannot fall within the scope of the present text). In all, it took several years for ECB to truly commit to an expansive monetary policy as a response to the ongoing multifold crisis, and it was in 2011 that ECB opened a strong expansionary program. Apart from the key interest rates changes shown in Table 2, money supply increased from $42 \%$ of eurozone GDP to $67 \%$ in 2016 (Rohatinski, 2019, p. 47). Croatian monetary policy is focused on inflation management with the exchange rate of kuna and euro as the anchor of this policy (HNB, 2019). Its anti-cyclical capabilities were dramatically undercut for this reason, as dramatic emissions were out of the question. The extremely high rate of euroization of the Croatian economy suggested that a depreciation of kuna would necessarily deepen the recession. However, in the 2010-2012 period, the Croatian Central Bank reduced the obligatory reserves in the banking sector, releasing liquidity and managing a non-traditional anti-cyclical approach (Rohatinski, 2019, p. 52). In this, the severe limitations of Croatian monetary policy were somewhat circumvented by a one-off non-traditional approach. It remains clear, however, that the HRK-EUR limbo has held the Croatian monetary policy hostage and that Croatia is so closely tied to euro issues, that it could not be considered "economically sovereign" even in the context of the crisis responses a decade ago. As we can observe from data in Table 2, Croatia is unique among the presented countries in following this aspect of restraint.

\section{Past and future Croatian economic independence}

In early 2020, the widespread measures intended to contain the COVID-19 epidemic have created a significant potential for a global recession. IMF initially projected the world GDP contraction for 2020 at -3\% in April 2020 (IMF, 2020a, p. 8), which was substantially lower than the 2009 global contraction of $-0.1 \%$ (ibid, p. 6 ). By June 2020, IMF substantially downgraded its prediction of 2020 contraction to $-4.9 \%$ (IMF, 2020b, p. 7). This recession is yet to fully develop, but it seems to be of world-shattering proportions. Particularly worrying are its underlying causes, i.e. halting of transport, movement and production. These suggest that, even when the recession has been overcome, the structure of global and national economic flows may change on a more permanent basis, dependent on the developments in epidemiological management.

Croatia itself is poised to experience a substantial contraction, originally projected at $-9 \%$ GDP in 2020 (IMF, 2020a, p. 20). Prior to these developments, Croatia was well positioned to enter the eurozone in roughly 2023. The stipulations of the Stability and Growth Pact obligatory for eurozone members were introduced in the Croatian legal structure in January 2018 and the strategy to introduce the euro was formally confirmed by the Croatian Government in May 2018 (Maletić et al., 2019, pp. 55-57). With its entrance in the ERM II mechanism in July 2020, Croatia is on its way to enter the deepest economic integration currently in force in the world, even as this may be complicated by the development of the recession. We are yet to witness the full development of this recession as well as the formulation of policy responses. So far, Croatia has responded in line with its previous crisis management positions. Monetary policy once more focused on the euro exchange rate and depended on non-traditional measures for the promotion of growth (HNB, 2020), while the proclaimed goal of fiscal policy response was to prevent an increase in overall expenditure (Lider, 2020). However, the specific nature of the COVID crisis has been recognized at the EU level and the escape clause for the fiscal rules of the Stability and Growth Pact was activated in March 2020. This may set an important precedent of a less punitive application of fiscal rules in crises.

We have outlined the institutional framework that Croatia will be maneuvering and focused on the elementary crisis management policy constrictions. The previous section has shown the three types of policy response that will no longer be available following the expected entry into the eurozone: depreciation episodes, independent monetary policy and fiscal stimulus. While some EU members could depreciate its currency against the euro to help 
the competitiveness of its exports, any eurozone member obviously cannot. And while some countries were able to spend their way to a higher GDP, stricter fiscal rules are now in place (although 2020 has seen restraint in their application). Finally, independent monetary policy in the general sense is only possible outside the eurozone, as ECB tries to make policy decisions for the benefit of all of the member economies at once, which would be possible only if the business cycles were harmonized and shocks were not asymmetric.

However, all of this is not likely to change Croatian economic policy for the worse as roughly the same tendencies have already been followed. We have shown that the Croatian crisis-related economic policies have been extremely subdued and pro-cyclical. The reasons for this are structural and historic as the Croatian economy became euroized in the context of the rough transition period and extremely high inflation rates which were resolved through a strong management of the exchange rate of the Croatian kuna and the German mark (and the euro after its creation). By the time of the 2008/09 events, it was impossible to depreciate the kuna for fears of causing an additional shock as well as making debt servicing entirely intransigent. This has also drawn the need for a very subdued monetary policy in order to relieve the pressure on the kuna. Likewise, the fiscal policy was far from a stimulus and can only be described as a very troubled form of fiscal consolidation. If the European Semester agenda intensifies further, we would hope to see even more productive pressures towards a reform of the public sector, which could improve Croatian fiscal policy by making the state function more as a provider of common goods and less as a massive and undemanding employer of bureaucrats. This would create the crucial structural impetus to enable more flexibility in fiscal policy geared toward growth and development.

\section{Conclusions and further research recommendations}

Our objective has been to assess the level of Croatian economic independence as an EU member. In sections 2 and 3 we have seen that national economic policies develop in specific institutional, po- litical and economic contexts and that the national preferences may be in conflict with the needs of the developing European integration. Of particular interest was the relationship between EU membership and economic sovereignty which we have found to be complex and fluid. While EU membership is by definition a process involving a transfer of a number of sovereign economic prerogatives, this should not be construed as negative as long as the process is undertaken by a democratic country. We have taken the view that the issue of possible infringement on Croatian national economic policy independence is best analyzed by surveying the measures undertaken after the 2008/09 shock, which largely predate Croatian EU accession in 2013. We have compared them to the experiences of other member states and contrasted them to the constrictions that would await Croatia upon eurozone membership. We are prepared to conclude that EU and future EMU membership does not represent pressures to significantly change the direction of extant economic policy. Therefore, while Croatia is and will be faced by significant policy constrictions, its loss of economic independence is not troubling.

We would like to suggest two general avenues for further research. Firstly, the next several years will be spent in economic recovery. The response to the currently developing recession will provide new insights into the functioning of the developing European integration project by focusing on the outlook of post-Brexit and post-COVID EU. Further research should not ignore the effects of such changes on the small member economies. Secondly, there is a possibility of a contrast between the stylized national preferences as identified in comparative institutional literature and the outlined constrictions to economic governance. As we have shown, there is already some research dealing with these transformations. However, new circumstances will need further research on the mutual interactions of various institutional arrangements (old, nationally specific and new, EU led) and their long term effects on growth. The primary issue is whether or not economic policy homogenization may produce adverse effects if it provides member states with growth models by which they come into close competition with one another. 


\section{REFERENCES}

1. Babić, Z. \& Lučev, J. (2019). Comparative analysis of economic and social policy development in Croatia and Slovenia. Problemy Polityki Społecznej. Studia i Dyskusje, 47(4), 47-71. https://doi.org/10.31971/16401808.47.4.2019.3

2. Becker, U. (2009). Open Varieties of Capitalism: Continuity, Change and Performances. Palgrave Macmillan. https://doi.org/10.1057/9780230240810

3. Blanchard, O., Dell'Ariccia, G. \& Mauro, P. (2010). Rethinking Macroeconomic Policy (IMF Staff Position Note No. 2010/03). Washington, DC: International Monetary Fund.

https://doi.org/10.5089/9781455224982.004.A001

4. BNB (2019). Base interest rate.

http://www.bnb.bg/Statistics/StBIRAndIndices/StBIBaseInterestRate/index.htm

5. BNR (2019). Statistics report: NBR's interest rates - entry into force date values. https://www.bnr.ro/Statistics-report-1124.aspx

6. Bohle, D. (2018). European integration, capitalist diversity and crises trajectories on Europe's Eastern periphery. New Political Economy, 23(2), 239-253. https://doi.org/10.1080/13563467.2017.1370448

7. Canale, R. R., De Grauwe, P., Foresti, P. \& Napolitano, O. (2018). Is there a trade-off between free capital mobility, financial stability and fiscal policy flexibility in the EMU?. Review of World Economics, 154(1), 177-201. https://doi.org/10.1007/s10290-017-0302-4

8. Carlin, W. \& Soskice, D. (2009). German Economic Performance: Disentangling the Role of Supplyside Reforms, Macroeconomic Policy and Coordinated Economy Institutions. Socio-Economic Review, 7(1), 67-99. https://doi.org/10.1093/ser/mwn021

9. CNB (2019). The main instruments of monetary policy. https://www.cnb.cz/en/monetary-policy/instruments

10. Crum, B. \& Merlo, S. (2020). Democratic legitimacy in the post-crisis EMU. Journal of European Integration, 42(3), 399-413. https://doi.org/10.1080/07036337.2020.1730347

11. Crum, B. (2018). Parliamentary accountability in multilevel governance: what role for parliaments in post-crisis EU economic governance?. Journal of European Public Policy, 25(2), 268-286. https://doi.org/10.1080/13501763.2017.1363270

12. Dabrowski, M. (2019). The Economic and Monetary Union: Past, Present and Future (CASE Research Paper, No. 497). Warsaw: Center for Social and Economic Research.

13. Danmarks Nationalbank (2019). Official interest rates.

http://www.nationalbanken.dk/en/marketinfo/official_interestrates/Pages/default.aspx

14. De Grauwe, P. \& Ji, Y. (2013). From Panic-Driven Austerity to Symmetric Macroeconomic Policies in the Eurozone. Journal of Common Market Studies, 51, 31-41. https://doi.org/10.1111/jcms.12042

15. Dixit, A. K. \& Stiglitz, J. E. (1977). Monopolistic competition and optimum product diversity. The American Economic Review, 67(3), 297-308.

16. ECB (2019). Key ECB interest rates.

https://www.ecb.europa.eu/stats/policy_and_exchange_rates/key_ecb_interest_rates/html/index. en.html

17. Eichengreen, B. (2014). The eurozone crisis: the theory of optimum currency areas bites back. Notenstein Academy White Paper Series, Notenstein Academy, March 2014.

18. ESM (2019). ESM Factsheet. https://www.esm.europa.eu/sites/default/files/20180530esmfactsheet.pdf

19. Gaysset, I., Lagoarde-Segot, T. \& Neaime, S. (2019). Twin deficits and fiscal spillovers in the EMU's periphery. A Keynesian perspective. Economic Modelling, 76, 101-116.

https://doi.org/10.1016/j.econmod.2018.07.023 
20. Genschel, P. \& Jachtenfuchs, M. (2018). From market integration to core state powers: the Eurozone crisis, the refugee crisis and integration theory. JCMS: Journal of Common Market Studies, 56(1), 178196. https://doi.org/10.1111/jcms.12654

21. Haas, J. S., D’Erman, V. J., Schulz, D. F. \& Verdun, A. (2020). Economic and fiscal policy coordination after the crisis: is the European Semester promoting more or less state intervention?. Journal of European Integration, 42(3), 327-344. https://doi.org/10.1080/07036337.2020.1730356

22. Hall, P. A. \& Gingerich, D. W. (2004). Varieties of Capitalism and Institutional Complementarities in the Macroeconomy: An Empirical Analysis (MPIfG Discussion Paper No. 04/5). Cologne: Max-PlanckInstitut für Gesellschaftsforschung.

23. Hall, P. A. \& Soskice, D. (2001). Varieties of Capitalism: The Institutional Foundations of Comparative Advantage. Oxford University Press.

24. HNB (2019). Active interest rates of the Croatian National Bank.

https://www.hnb.hr/documents/20182/296265a5-9a82-43ea-8d6e-2d17bed45edd

25. HNB (2020). CNB Council: Reserve requirement rate reduced from 12\% to 9\%. https://www.hnb.hr/-/ savjet-hnb-a-stopa-za-obracun-obvezne-pricuve-smanjena-s-12-na-9-

https://www.riksbank.se/en-gb/monetary-policy

26. Hodson, D. (2015). Policy-Making under Economic and Monetary Union: Crisis, Change and Continuity. In Wallace, H. et al. (Eds.), Policy-Making in the European Union (pp. 166-195). Oxford University Press.

27. Howarth, D. \& Verdun, A. (2020). Introduction to 'Economic and Monetary Union at Twenty: A Stocktaking of A Tumultuous Second Decade. Journal of European Integration, 42(3), 287-293.

https://doi.org/10.1080/07036337.2020.1730348

28. Imbs, J. \& Pauwels, L. (2019). Real convergence in the EMU. 20 years of European Economic and Monetary Union, Conference proceedings (pp. 36-70).

29. IMF (2019). World Economic Outlook October 2019.

https:/www.imf.org/external/pubs/ft/weo/2019/02/weodata/index.aspx

30. IMF (2020a). World Economic Outlook, April 2020: The Great Lockdown. https://www.imf.org/en/Publications/WEO/Issues/2020/04/14/weo-april-2020

31. IMF (2020b). World Economic Outlook Update, June 2020.

https://www.imf.org/en/Publications/WEO/Issues/2020/06/24/WEOUpdateJune2020

32. Jančić, D. (2016). National parliaments and EU fiscal integration. European Law Journal, 22(2), 225249. https://doi.org/10.1111/eulj.12172

33. Johnston, A. \& Regan, A. (2018). Introduction: Is the European Union Capable of Integrating Diverse Models of Capitalism?. New Political Economy, 23(2), 145-159.

https://doi.org/10.1080/13563467.2017.1370442

34. Kletzer, K. M. (2018). Sovereign Debt. In Jones, G. (Ed.), The New Palgrave Dictionary of Economics (pp. 12721-12725). Palgrave Macmillan. https://doi.org/10.1057/978-1-349-95189-5_2377

35. Krugman, P. (2012). End This Depression Now! WW Norton \& Company.

36. Krugman, P. (2013). Revenge of the Optimum Currency Area. NBER Macroeconomics Annual, 27(1), 439-448. https://doi.org/10.1086/669188

37. Lider (2020). Rebalans proračuna: Uštede će osjetiti svi, ukupni rashodi ostaju kao što su planirani. https://www.lider.media/poslovna-scena/hrvatska/rebalans-proracuna-ustede-ce-osjetiti-svi-ukupnirashodi-ostaju-kao-sto-su-planirani-131315

38. Lütz, S. \& Kranke, M. (2014). The European rescue of the Washington Consensus? EU and IMF lending to Central and Eastern European countries. Review of International Political Economy, 21(2), 310-338. https://doi.org/10.1080/09692290.2012.747104

39. Maletić, I., Galinec, D., Japunčić, T. \& Župan, S. (2019). Five years of the Republic of Croatia in the European semester. Ured zastupnice u Europskom parlamentu Ivane Maletić. 
40. McKinnon, R. I. (1963). Optimum currency areas. The American Economic Review, 53(4), 717-725.

41. MNB (2019). Base rate history. https://www.mnb.hu/en/Jegybanki_alapkamat_alakulasa

42. Mody, A. (2018). Eurotragedy: A Drama in Nine Acts. Oxford University Press. https://doi.org/10.1093/oso/9780199351381.001.0001

43. Mongelli, F. P. (2002). "New" views on the optimum currency area theory: what is EMU telling us? (ECB Working Paper No. 138). Frankfurt am Main: European Central Bank.

44. Mundell, R. A. (1961). A theory of optimum currency areas. The American Economic Review, 51(4), 657-665.

45. NBP (2019). Interest rates (1998-2015).

http://www.nbp.pl/homen.aspx?f=/en/dzienne/stopy_archiwum.htm

46. Nölke, A. (2016). Economic causes of the Eurozone crisis: the analytical contribution of Comparative Capitalism. Socio-Economic Review, 14(1), 141-161. https://doi.org/10.1093/ser/mwv031

47. Obstfeld, M. (2013). Finance at Center Stage: Some Lessons of the Euro Crisis. Economic Papers, 493, $1-55$.

48. Padoa-Schioppa, T. (2004). The euro and its central bank: Getting united after the union. MIT Press. https://doi.org/10.7551/mitpress/2846.001.0001

49. Riksbank (2019). Monetary policy. https://www.riksbank.se/en-gb/monetary-policy

50. Rohatinski, Ž. (2019). Kriza u Hrvatskoj. Ljevak.

51. Sandbu, M. (2015). Europe's Orphan: The Future of the Euro and the Politics of Debt. Princeton University Press. https://doi.org/10.1515/9781400873425

52. Schmidt, V. A. (2016). The new EU governance: new intergovernmentalism, new supranationalism, and new parliamentarism (IAI Working Paper No. 16). Rome: Istituto Affari Internazionali.

53. Stiglitz, J. E. (2016). The Euro: How a Common Currency Threatens the Future of Europe. WW Norton \& Company.

54. Târlea, S., Bailer, S., Degner, H., Dellmuth, L. M., Leuffen, D., Lundgren, M., Tallberg, J. \& Wasserfallen, F. (2019). Explaining governmental preferences on economic and monetary union reform. European Union Politics, 20(1), 24-44. https://doi.org/10.1177/1465116518814336

55. Verdun, A. C. \& Zeitlin, J. (2018). Introduction: The European Semester as a new architecture of EU socioeconomic governance in theory and practice. Journal of European Public Policy, 25(2), 137-148. https://doi.org/10.1080/13501763.2017.1363807 